\title{
Pentingnya Determinasi Diri Bagi School Well-Being Siswa SMP
}

\author{
Fauzi Rahman, Hafizh Zain Abdillah, Nurul Hidayah \\ Magister Psikologi Sains Universitas Ahmad Dahlan Yogyakarta
}

\begin{abstract}
School well-being is important for students for optimal learning processes and personal development. This study aims to empirically examine how self-determination predicts school well-being in junior high school students in Yogyakarta using a linear regression analysis technique of 123 participants selected based on random cluster sampling. Measurements were made using 18 items of self-determination scale (Cronbach's $\alpha=0.83$ ) and 30 items of school well-being scale (Cronbach's $\alpha=0.95)$. The results showed a regression coefficient $(t=2.062)$ with a significance level $p=0.041(p<0.05)$, which means that self-determination can predict the school well-being of junior high school students with an effective contribution of 5.17 percent.
\end{abstract}

Keywords: Junior High School Student; School Well-being; Self Determination

\begin{abstract}
Abstrak
School well-being penting bagi siswa untuk proses pembelajaran dan perkembangan pribadi yang optimal. Penelitian ini bertujuan untuk menguji secara empiris bagaimana determinasi diri memprediksi school well-being pada siswa SMP di Kota Yogyakarta menggunakan teknik analisa regresi linier terhadap 123 partisipan yang terpilih berdasarkan cluster random sampling. Pengukuran dilakukan menggunakan 18 aitem skala determinasi diri (koefisien $\alpha$ Cronbach $=0,83$ ) dan 30 aitem skala school well-being (koefisien $\alpha$ Cronbach $=0,95$ ). Hasil analisa data menunjukkan nilai koefisien regresi $(t)$ sebesar 2,062 dengan taraf signifikansi sebesar 0,041 $(\mathrm{p}<0,05)$ yang berarti bahwa determinasi diri dapat memprediksi school well-being siswa SMP dengan sumbangan efektif sebesar 5,17 persen.
\end{abstract}

Kata kunci: Siswa SMP; School Well-being; Determinasi Diri,

Sekolah memiliki peran yang besar dalam perkembangan siswa. Memastikan para siswa merasa bahagia dan puas saat berada di lingkungan sekolah idealnya harus menjadi fokus perhatian banyak pihak yang terlibat di sekolah. Para siswa yang merasa puas dengan sekolah mereka akan mengembangkan sikap positif dalam proses belajar-mengajar serta dapat meningkatkan prestasi mereka (N. H. Hidayah dkk., 2016).

Konsepsi mengenai kebahagiaan dan kepuasan siswa terhadap sekolah oleh para ilmuwan dinyatakan sebagai school related well-being atau school well-being (Anne Konu \& 
Rimpelä, 2002; Tian dkk., 2013). Sejumlah ilmuwan mengembangkan konsep school well-being dengan model teoritis yang didasarkan pada konsep kesejahteraan secara sosiologis menurut Allardt (A. Konu dkk., 2002; Anne Konu \& Rimpelä, 2002). Penelitian ini bertujuan untuk melihat bagaimana school well-being siswa dipengaruhi variabel lain, dalam hal ini yaitu determinasi diri. Model konseptual school well-being yang dikemukakan oleh Konu dan Rimpelä (2002) melihat kesejahteraan dari sudut pandang siswa yang terdiri dari empat aspek yaitu having (kondisi sekolah), loving (hubungan sosial), being (pemenuhan diri), dan health (status kesehatan).

Studi pendahuluan peneliti pada siswa suatu SMP di Kota Yogyakarta menunjukan bahwa school well-being pada siswa masih rendah. Hal tersebut dapat dilihat pada dimensi having, siswa merasa kurang nyaman akibat polusi suara dari luar karena letak sekolah yang berada di pinggir jalan raya; atau dimensi loving, misalnya, ada siswa yang merasa hubungan dengan teman sebaya kurang baik dikarenakan konflik, bullying, gang, intimidasi dan ancaman atau juga dalam dimensi being, siswa merasa dukungan sekolah dan peran sekolah terhadap organisasi siswa kurang optimal; serta dalam dimensi health, bahwa siswa merasa kelelahan dan stress karena banyak tugas. Kondisi tersebut menunjukan bahwa masih belum tercapai adanya kesejahteraan di sekolah (school well-being) yang ditandai dengan rasa ketidaknyamanan, ketidakpuasan, serta kualitas kehidupan di sekolah yang kurang baik pada SMP di Kota Yogyakarta.

Ketidaknyamanan yang dirasakan siswa seperti dimaksud, bisa jadi karena siswa SMP yang masih dalam perkembangan remaja awal sedang mengalami masa transisi baik transisi secara perkembangan dari masa anak anak ke dewasa, serta transisi sekolah dari SD ke SMP turut mempengaruhi kesejahteraan remaja sebagai siswa di sekolah (Shoshani \& Slone, 2013). Hidayah (2018) mengungkapkan bahwa terdapat kecenderungan penurunan kepuasan terhadap sekolah sesuai dengan meningkatnya usia siswa. Kecenderungan tersebut dipengaruhi oleh persepsi siswa terhadap kemampuan akademiknya. Digambarkan bahwa penurunan ini melalui berbagai faktor, termasuk menurunnya perhatian guru terhadap perkembangan siswa secara individu, tingkat kompetisi yang lebih besar di level yang lebih tinggi, dan tekanan yang terkait dengan peralihan sekolah (Hidayah, 2018). 
Penelitian tentang kesejahteraan di sekolah, menunjukkan bahwa siswa dengan kesejahteraan tinggi akan menunjukkan peningkatan prestasi akademik dan penurunan munculnya masalah-masalah perilaku, seperti membolos, perilaku merokok, penggunaan narkoba, dan kenakalan (Suldo \& Huebner, 2004). Program school well-being menjadi penting dan bermanfaat jika diterapkan di sekolah, karena siswa yang merasa bahagia, sejahtera, dan sehat dalam mengikuti pelajaran di kelas, dapat belajar secara efektif dan dapat berkontribusi secara positif pada sekolah maupun lebih luas lagi pada komunitas. Suatu studi mengungkapkan bahwa secara umum, pengalaman emosional yang menyenangkan di sekolah cenderung dikaitkan dengan penggunaan strategi pembelajaran yang lebih efektif, perhatian yang lebih fokus, serta performa akademik yang baik (Schutz dkk., 2011). Sebaliknya, siswa yang merasa tidak nyaman di sekolah, secara khusus melaporkan perasaan cemas, menunjukkan rendahnya kemampuan kognitif dan prestasi belajar, serta cenderung mengalami tekanan psikologis dan kesehatan yang buruk (Schutz dkk., 2011). Berbagai temuan ini menunjukkan bahwa sangat penting untuk mengelola school well-being pada siswa.

Berdasarkan teori determinasi diri (self determination theory), determinasi diri telah terbukti melalui sejumlah penelitian dapat menentukan well-being (Adams dkk., 2017; Baard dkk., 2004; Deci \& Ryan, 2008; Levesque dkk., 2011; Niemiec \& Ryan, 2009). Deci dan Ryan (1985) mendefinisikan determinasi diri sebagai kualitas fungsi manusia yang melibatkan pengalaman untuk memilih, atau adanya pengalaman akan internal perceived locus of causality (lokus sebab-akibat yang dirasakan secara internal). Sedangkan menurut Murcia, Gimeno, dan Camacho (2007) determinasi diri merupakan konsep motivasi pada individu yang memiliki keterkaitan dengan perkembangan dan fungsi dari kepribadian individu pada konteks sosial.

Di antara konsep dasar dari determinasi diri adalah konsepsi mengenai motivasi dan kebutuhan dasar psikologis (basic psychological needs). Konsepsi dasar berikutnya adalah mengenai kebutuhan dasar psikologis (basic psychological needs), yakni suatu set kebutuhan psikologis yang harus dipenuhi untuk memunculkan keberfungsian psikologis yang efektif serta mendorong kesehatan psikologis, yakni kebutuhan akan kompetensi (competence), otonomi (autonomy), dan keterhubungan (relatedness) (Deci \& Ryan, 2008). Kegagalan untuk memenuhi semua kebutuhan ini akan dimanifestasikan dalam pertumbuhan (growth), integritas 
(integrity), dan kesejahteraan (wellness) yang berkurang (Ryan \& Deci, 2017). Kepuasan dan kekecewaan terhadap pemenuhan kebutuhan psikologis bervariasi dalam diri seseorang menurut waktu, konteks, dan interaksi sosial (Ryan \& Deci, 2017). Lebih lanjut dijelaskan Ryan dan Deci (2017) bahwa faktor atau peristiwa apa pun yang menghasilkan variasi dalam kepuasan atau kekecewaan terhadap pemenuhan kebutuhan juga akan menghasilkan variasi dalam kesejahteraan (wellness).

Berdasarkan pemaparan sebelumnya, artikel ini bertujuan untuk menjawab pertanyaan, apakah determinasi diri dapat memprediksi school well-being siswa SMP di Kota Yogyakarta? Pertanyaan tersebut akan dijawab dengan hipotesis peneliti, yakni terdapat hubungan positif antara determinasi diri dengan school well-being siswa SMP di Kota Yogyakarta, yang berarti semakin tinggi determinasi diri maka semakin tinggi pula school well-being, begitu pula sebaliknya, sehingga dapat dinyatakan bahwa determinasi diri dapat memprediksi school wellbeing siswa SMP di Kota Yogyakarta.

\section{Metode}

Metode yang digunakan dalam penelitian adalah penelitian kuantitatif. Analisis data yang digunakan dalam penelitian ini adalah analisis regresi linear dengan bantuan program SPSS 24.0 for windows evaluation version. Jumlah populasi seluruhnya berjumlah 807 siswa yang terdiri dari 390 siswa kelas VIII dan 411 siswa kelas IX. Sampel penelitian berjumlah 123 siswa yang dipilih secara cluster random sampling yang terdiri 65 siswa SMP A dan 58 siswa SMP B, kedua sekolah ada di Kota Yogyakarta. Variabel penelitian meliputi variabel bebas (X) dan variabel terikat $(\mathrm{Y})$. Variabel bebas $(\mathrm{X})$ yakni determinasi diri dan variabel terikat $(\mathrm{Y})$ yakni school well-being. Pengukuran masing-masing variabel menggunakan 18 aitem skala determinasi diri yang dikembangkan berdasarkan teori determinasi diri Deci dan Ryan (2000) dan 30 aitem skala school well-being yang dikembangkan berdasarkan model teoritis dari Konu dan Rimpelä (2002). Reliabilitas masing-masing skala adalah amat reliabel dengan nilai koefisien $\alpha$ Cronbach sebesar 0,83 (skala deterrminasi diri) dan 0,95 (skala school well-being). 


\section{H a s i 1}

Hasil analisa deskriptif menunjukkan kategorisasi subjek penelitian pada masingmasing variabel yakni sebagaimana tersaji pada tabel. 1 berikut.

Tabel 1

Kategorisasi Subjek Berdasarkan Variabel

\begin{tabular}{lllll}
\hline Kategori & \multicolumn{2}{c}{ School Well-being } & \multicolumn{3}{l}{ Determinasi Diri } \\
\cline { 2 - 5 } & Frekuensi & $\%$ & Frekuensi & $\%$ \\
\hline Tinggi & 23 & $18,7 \%$ & 19 & $15,4 \%$ \\
Sedang & 84 & $68,3 \%$ & 87 & $70,7 \%$ \\
Rendah & 16 & $13 \%$ & 17 & $13,8 \%$ \\
\hline
\end{tabular}

Berdasarkan tabel. 1 diketahui bahwa untuk variabel school well-being terdapat 23 siswa yang masuk kategori tinggi, 84 siswa dalam kategori yang sedang dan 16 siswa dalam kategori rendah. Deskripsi data determinasi diri dapat dilihat bahwa terdapat 19 siswa yang memiliki skor yang tinggi, 87 siswa dalam kategori sedang dan 17 siswa dalam kategori yang rendah. Hal ini menunjukan bahwa mayoritas subjek dalam penelitian ini memiliki school well-being dan determinasi diri dalam kategori sedang.

Selanjutnya, hasil uji regresi linier menunjukkan bahwa determinasi diri dapat memprediksi school well-being. Berdasarkan hasil perhitungan diketahui bahwa nilai t sebesar 2,062 dengan taraf signifikansi (nilai $\mathrm{p})$ sebesar 0,041 ( $\mathrm{p}<0,05)$, maka dinyatakan signifikan, yang berarti determinasi diri dapat memprediksi school well-being secara signifikan. Hipotesis yang diajukan teruji kebenarannya, data yang diperoleh menunjukan determinasi diri dapat memprediksi school well-being. Sumbangan efektif variabel determinasi diri terhadap school wellbeing dihitung menurut rumus $\mathrm{SE}=\beta$ x zero $\times 100$ persen, dan didapat sebesar 5,17 persen. Berikut adalah tabel 2 sebagai hasil perhitungan uji regresi linier. 
Tabel 2

Hasil Perhitungan Uji Regresi Linier

\begin{tabular}{lllll}
\hline Variabel & Nilait & Sig. & Beta & Zero Order \\
\hline Determinasi diri & 2,062 & 0,041 & 0,135 & 0,383 \\
\hline
\end{tabular}

Variabel terikat: School well-being $(\mathrm{p}<0,05)$

\section{Pembahasan}

Berdasarkan hasil analisis yang dilakukan, hipotesis yang diajukan dapat terbukti kebenarannya yaitu bahwa determinasi diri dapat menentukan school well-being. Hasil ini menunjukkan bahwa terdapat peran positif, yaitu semakin tinggi determinasi diri maka ada kecenderungan peningkatan school well-being siswa SMP Kota Yogyakarta. Berdasarkan perhitungan, kontribusi variabel determinasi diri terhadap school well-being yakni sebesar 5,17 persen.

Hasil penelitian ini menunjukkan kecenderungan yang sejalan dengan yang diungkapkan oleh Levesque, Stanek, Zuehlke, dan Ryan (2004) bahwa perasaan otonomi dan kompeten sebagai indikator dari determinasi diri adalah penting bagi kesejahteraan subjektif mahasiswa. Diungkapkan pula bahwa dalam lingkungan pendidikan di Amerika Utara, perasaan akan aspek-aspek determinasi diri, yakni otonomi, kompeten, dan keterhubungan dianggap penting bagi kesejahteraan subjektif siswa di sekolah (Levesque dkk., 2004). Hal ini berarti bahwa determinasi diri memberi pengaruh terhadap kesejahteraan (wellbeing) siswa dalam konteks pengalamannya di sekolah. Dalam pandangan Tian, Liu, Huang, dan Huebner (2013), konsep kesejahteraan subjektif (subjective wellbeing) yang diterapkan pada siswa dalam konteks yang spesifik di sekolah dapat dimaknai sebagai school well-being.

Tian (2008) merumuskan bahwa school well-being muncul sebagai hasil dari interaksi antara kepuasan bersekolah (school satisfaction), perasaan positif (positive affect) dan perasaan negatif (negative affect) siswa di sekolah. Dijelaskan Tian, Liu, Huang, dan Huebner (2013) bahwa kepuasan bersekolah (school satisfaction) mengacu pada evaluasi kognitif secara umum mengenai kehidupan sekolah, yang timbul dari pengalaman keseharian siswa di sekolahnya; 
sementara perasaan positif (positive affect) di sekolah yakni banyaknya kemunculan emosi positif yang siswa alami khususnya selama berada di sekolah, seperti perasaan santai, menyenangkan, atau bahagia; dan perasaan negatif (negative affect) di sekolah merujuk pada frekuensi munculnya emosi negatif, seperti perasaan kesal, bosan, atau tertekan.

Determinasi diri dibutuhkan siswa SMP Kota Yogyakarta untuk menghadapi masalahmasalah dalam kehidupan sehari-hari agar dapat meningkatkan school well-being-nya. Terpenuhinya kebutuhan dasar psikologis siswa sebagai indikator akan determinasi diri yang terdiri dari terpenuhinya kebutuhan otonomi, kompetensi, dan keterhubungan siswa menyebabkan siswa merasa puas dan bahagia berada di lingkungan sekolahnya. Perasaan otonomi terkait dengan keberadaan individu siswa sebagai pribadi yang mandiri, misalnya dalam pengambilan keputusan, siswa perlu untuk merasa leluasa untuk menentukan keputusan berdasarkan aspirasi dirinya sendiri sehingga siswa akan merasa puas dan bahagia dengan keputusannya. Perasaan kompeten merupakan kemampuan yang dimiliki individu dalam mendorong tindakan yang akan dilakukannya untuk mencapai tujuan. Niemiec dan Ryan (2009) mengungkapkan bahwa kebutuhan untuk berperilaku dan merasa kompeten dibutuhkan dalam interaksi individu dengan individu lain, dalam mengerjakan aktivitas dan memenuhi tugas, begitu pula dalam konteks yang lebih besar, sehingga demikian siswa akan merasa senang bila berhasil mengelola dirinya dalam interaksi dengan siswa lain, memenuhi tugas dan aktivitas sekolah, atau tugas-tugas dan aktivitas yang lain. Sedangkan perasaan keterhubungan (relatedness) yakni berkaitan dengan hubungan individu dengan orang lain. Levesque, Copeland, Pattie, dan Deci (2011) menjelaskan bahwa para siswa mendapat banyak kepuasan dari melihat teman-teman mereka di sekolah setiap hari, bertemu orang-orang baru, dan mengenal lebih dekat guru-guru mereka; bersama dengan teman-teman di sekolah menjadi bagian penting dari pergi ke sekolah dan memberikan kontribusi sejauh mana siswa dapat menganggap sekolah mereka memuaskan dan menyenangkan. Selain itu, ketika siswa mengembangkan hubungan yang sehat dengan guru dan anggota staf lainnya, tingkat produktivitas dan minat mereka di kelas meningkat; hal ini juga mengarah pada kepuasan yang lebih besar dan kenikmatan aktual dalam pengalaman akademik siswa (Levesque dkk., 2011). 


\section{Kesimpulan}

Berdasarkan hasil penelitian dan pembahasan dapat disimpulkan bahwa determinasi diri dapat memprediksi school well-being. Hasil tersebut membuktikan bahwa semakin tinggi determinasi diri maka ada kecenderungan peningkatan school well-being siswa SMP Kota Yogyakarta, oleh karenanya determinasi diri merupakan variabel penting yang dapat menentukan school well-being siswa.

Saran

Bagi peneliti selanjutnya, peneliti menyarankan agar kajian selanjutnya menggunakan variabel-variabel lainnya yang dimungkinkan berkontribusi bagi peningkatan school well-being siswa SMP. Variabel tersebut di antaranya, self-esteem, penilaian terhadap makna hidup, optimisme, penyesuaian diri, dan tipe kepribadian.

\section{Referensi}

Adams, N., Little, T. D., \& Ryan, R. M. (2017). Self-determination Theory. Development of SelfDetermination Through the Life-Course, 55(1), 47-54.

Baard, P. P., Deci, E. L., \& Ryan, R. M. (2004). A Motivational Basis of Performance and Weil-Being in Two Work Settings. Journal of applied social psychology, 34(10), 2045-2068.

Deci, E. L., \& Ryan, R. M. (1985). Intrinsic motivation and self-determination in human behavior. Plenum.

Deci, E. L., \& Ryan, R. M. (2000). The "What" and "Why" of Goal Pursuit: Human Needs and The Self Determination of Behavior. Department of Psychology University of Rochester.

Deci, E. L., \& Ryan, R. M. (2008). Self-Determination Theory: A Macrotheory of Human Motivation, Development, and Health. Canadian Psychology, 49(3), 182-185.

Hidayah, N. (2018). Parents' Perspective About Students' School Well-Being. Proceeding of International Conference On Child-Friendly Education, 99-103.

Hidayah, N. H., Pali, M., Ramli, M., \& Hanurawan, F. (2016). Students' Well-Being Assessment at School. Journal of Educational, Health and Community Psychology, 5(1), 62-71.

Konu, A., Alanen, E., Lintonen, T., \& Rimpelä, M. (2002). Factor Structure of The School WellBeing Model. Health Education Research, 17(6), 732-742.

Konu, A. I., \& Lintonen, T. P. (2006). School well-being in Grades 4-12. Health Education Research, 21(5), 633-642.

Konu, Anne, \& Rimpelä, M. (2002). Well-Being in Schools: A Conceptual Model. Health Promotion International, 17(1), 79-87. 
Levesque, C., Copeland, K. J., Pattie, M. D., \& Deci, E. L. (2011). Intrinsic and Extrinsic Motivation. Dalam S. Järvelä (Ed.), Social and emotional aspects of learning (hlm. 15-20). Elsevier.

Levesque, C., Stanek, L. R., Zuehlke, A. N., \& Ryan, R. M. (2004). Autonomy and Competence in German and American University Students: A Comparative Study Based on SelfDetermination Theory. Journal of Educational Psychology, 96(1), 68-84.

Murcia, J. A. M., Gimeno, E. C., \& Camacho, A. M. (2007). Measuring Self-Determination Motivation in a Physical Pitness Setting: Validation of The Behavioral Regulation in Exercise Questionnaire-2 (BREQ-2) In a Spanish Sample. Journal of Sports Medicine and Physical Fitness, 47(3), 366-374.

Niemiec, C. P., \& Ryan, R. M. (2009). Autonomy, Competence, and Relatedness in the Classroom: Applying Self-Determination Theory to Educational Practice. Theory and Research in Education, 7(2), 133-144.

Ryan, R. M., \& Deci, E. L. (2017). Self-Determination Theory: Basic Psychological Needs in Motivation, Development, and Wellness. The Guilford Press.

Schutz, P. A., Quijada, P. D., de Vries, S., \& Lynde, M. (2011). Emotion in Educational Contexts. Dalam S. Järvelä (Ed.), Social and Emotional Aspects of Learning (hlm. 64-69). Elsevier.

Shoshani, A., \& Slone, M. (2013). Middle School Transition From The Strengths Perspective: Young Adolescents' Character Strengths, Subjective Well-Being, and School Adjustment. Journal of Happiness Studies, 14(4), 1163-1181.

Suldo, S. M., \& Huebner, E. S. (2004). Does Life Satisfaction Moderate The Effects of Stressful Life Events on Psychopathological Behavior During Adolescence? School Psychology Quarterly, 19(2), 93-105.

Tian, L. (2008). Developing Scale For School Well-Being In Adolescents. Psychological Development and Education, 24(3), 100-106.

Tian, L., Liu, B., Huang, S., \& Huebner, E. S. (2013). Perceived Social Support and School WellBeing Among Chinese Early and Middle Adolescents: The Mediational Role of SelfEsteem. Social Indicators Research, 113(3), 991-1008.

\begin{tabular}{|l|l|l|l|l|}
\hline Submit & Review & Revisi & Diterima & Publis \\
\hline 07-04-2020 & 29-04-2020 sd 05-06-2020 & 02-07-2020 & 03-07-2020 & 04-07-2020 \\
\hline
\end{tabular}

Fauzi Rahman, Hafizh Zain Abdillah, Nurul Hidayah

Magister Psikologi Sains Universitas Ahmad Dahlan Yogyakarta

Email : fauzi1707044024@webmail.uad.ac.id, hafizhzainabd@gmail.com, nurul.hidayah@psy.uad.ac.id 